\title{
Disengagement From the Labor Contract: The Problem and a Proposal
}

Richard L. Epstein**

I

BACKGROUND

The parochial view of union history is that of the effort of employees, in gradually increasing concert, to obtain from employers improved hours, wages, and conditions of employment. The vehicle of change is what we know as collective bargaining.

The organization of employees in pursuit of contracts and improvements was confronted with a variety of legal barriers which effectively stifled substantial progress throughout the 19 th century and beyond. The various state jurisdictions employed one or more theories of law to hold that concerted employee activity was illegal, and thus enjoinable. ${ }^{1}$

Although thereafter some of the restraints on employee organization were removed, it was not until the elasticized "commerce clause" 2 of the Constitution was brought into the play that organized labor achieved some protection for its means and its ends. The first significant step was the enactment of the Anti-Injunction Act in 1932. ${ }^{3}$ By prohibiting the issuance of federal court injunctions in labor disputes, the act gave organized employees the first substantial protection of their means. In 1935, the development of organized labor turned a corner when the federal government legislated a guarantee to organized labor of the ends it sought-the collective bargaining relationship. ${ }^{4}$ The National Labor Relations Act was primarily significant for its requirenient that where a majority of employees in an appropriate unit so desired, their employer was compelled to recognize their designated representative and negotiate in good faith a collective bargaining agreenient.

The subsequent development of labor law and labor relations has had two major aspects. The first of these is the matter of the duties of employ-

* Member, New York Bar.

${ }^{1}$ See, e.g., People v. Fisher, 14 Wend. 9 (N.Y. Sup. Ct. 1835).

2It is, of course, from the commerce clause of the Constitution that labor legislation is derived.

${ }^{3}$ Norris-LaGuardia Act, 47 Stat. 70-73 (1932), 29 U.S.C. \$§ 101-10, 113-15 (1958).

4 The National Labor Relations Act (Wagner Act), 49 Stat. 449 (1935), 29 U.S.C. §§ 151-68 (1958), amended by The Labor Management Relations Act (Taft-Hartley Act), 61 Stat. 136 (1947), 29 U.S.C. $\$ \$ 141-44,151-68,171-82,185-88$ (1958), and The Labor Management Reporting and Disclosure Act of 1959 (Landrum-Griffin Act), 73 Stat. 519 (1959), 29 U.S.C. $\$ \$ 153$, 158-60, 164, 186-87 (Supp. II, 1960). 
ers and employee representatives to negotiate with one another and to conduct their relationship without discrimination, coercion, and restraint upon the employees. Secondly, there is the problem of determining the essential legal character of the labor contract.

The collective bargaining aspect has been the steady concern of legislation and of the conglomerate of decisions of the National Labor Relations Board and the federal appellate courts. Taken together they have formed a gradually expanding fabric of regulatory provisions. As a result, employers, employees, and unions may know with reasonable certainty their respective rights and responsibilities in the matters of:

1. Recognizing a umion as the bargaining agent of employees;

2. The unit deemed appropriate for that relationship;

3. Protection of employees from discrimination, coercion, or restraint by both employers and unions with respect to their membership or nonmenibership in a labor organization;

4. The circnmstances, including method, purpose, and effect, under which striking, picketing, and boycotting are permitted or prohibited; and

5. The nature of the duty to negotiate and to reach agreement.

While the labor acts and the National Labor Relations Board have prescribed the duty to make a contract, the requirements for doing so, and a forum to redress its breach, neither has attempted to define the nature of that agreement. This omission has three important consequences. First, it leaves to the courts generally and to a multitude of individual arbitrators the responsibility to consider and determine the nature of the collective contract. As a result, there is today no uniform view of the nature of the contract. Second, without agreenient as to the nature of the collective bargaining agreement, it is difficult to predict the legal consequences which shall attach to areas of controversy as to which the agreement is either ambiguous or silent. Third, the point at which the decider is called in is after the event, and either party may, accordingly, pay a heavy penalty, due not to imperfect judgment, but to a wrong guess. ${ }^{5}$

With the progress of industrial developinent and the growing complexity of management, production, marketing, and personnel relations, the nature of the collective bargaining agreement is taking on mounting importance. Over the course of the last two decades, this has been reflected in the mcreasing concern for and more frequent occurrence of having to inter-

5 Dean Shulman asserted that the arbitrator, being privately and voluntarily selected by the affected parties, should be called on to decide the day-to-day problems that arise in the life and administration of a union contract. Shulman, Reason, Contract, and Law in Labor Relations, 68 HARv. L. Rev. 999 (1955). 
pret the management's rights clause ${ }^{6}$ of the agreement. It is reflected also in the attention that has been given to the nature of the agreement by such notable observers as Harry Shulman, ${ }^{7}$ Neil Chamberlain, ${ }^{8}$ and Archibald $\mathrm{Cox}^{9}$ who have written on what the nature of the collective bargaining agreement is considered to be and what it should be.

Moreover, the number of collective agreements has increased, as have the number of arbitrators and the occasions of issues and awards. In each instance, the arbitrator has applied one of three schools of thought in arriving at an award: first, everything not provided for in the agreement is reserved to management; second, everything not provided for in the agreement must be negotiated between the employer and the umion; and third, the matter should be determined by what the arbitrator would in his judgment construe to be the general intent of the parties and the past practice between the parties, and by the conscience of the arbitrator applied to the equities.

It was against this background of uncertainty that the Supreme Court of the United States was petitioned into the maelstrom and came forth with the philosophy of contract and labor relations expressed in the so-called trilogy. ${ }^{10}$ These Supreme Court decisions continue to have a notable impact on the problem of contract nature not only because of what they decided, but particularly for the essay by Justice Douglas on what is a collective bargaining relationship. ${ }^{11}$ The occasion of the trilogy marked the climax of the long quarrel over the nature of the collective agreement and set the stage for a more immediate problem in industrial relations. ${ }^{12}$

"Frequently referred to also as the "management functions" clause, or the "management prerogatives" clause.

7 Shulman, supra note 5.

8 Chamberlain, Collective Bargaining and the Concept of Contract, 48 CoLom. L. Rev. 829 (1948).

${ }^{\circ}$ Cox, The Legal Nature of Collective Bargaining Agreements, 57 MIcE. L. REv. 1 (1958).

10 On June 20,1960, the Supreme Court decided three related cases, the first two of which concerned the arbitrability of disputes claimed by the respective employers to be foreclosed by the terms of the contract. United Steelworkers v. American Mfg. Co., 363 U.S. 564 (1960); United Steelworkers v. Warrior \& Gulf Nav. Co., 363 U.S. 574 (1960); United Steelworkers v. Enterprise Wheel \& Car Corp., 363 U.S. 593 (1960).

11 United Steelworkers v. Warrior \& Gulf Nav. Co., 363 U.S. 574, 578-85 (1960).

12 The revolutionary changes in industry stimulated by science and engimeering furnish a second reason for expecting changes in collective bargaining. Industrial changes will bring in their wake serious economic dislocations. Even under the most favorable conditions, the dislocations will give rise to temporary unemployment and loss of pertinent skills. Even the immediate transfer to a new job with another employer may involve loss of seniority and pension rights. With anything less than extraordinary luck, the dislocations mean serious unemployment and depressed areas like the iron and steel towns of Pennsylvania and the coal fields of West Virginia.

"The Future of Collective Bargaining," Address by Hon. Archibald Cox to the Section of Labor Law, in 1961 Procezdings, American Bar Association 17. 
THE NEW PROBLEM: DISENGAGEMENT

The manner in which the nature of the union contract is viewed has traditionally been an outgrowth of what are, by and large, day-to-day operational problems. The first hint of the new area of concern arose out of the management desire and decision to subcontract selected work processes or maintenance functions. The significance of subcontracting is twofold:

1. The collective agreement is frequently silent on the subject; and

2. Subcontracting involves the removal of jobs out from under the employees who are covered by a collective agreement.

What the employer does, in effect, is to disengage from the contract the particular plant function that is discontinued. The questions are these: May an employer disengage a collective agreement, and, if he may, under what circumstances? Of itself, subcontracting may not be a matter of wide significance. Its consideration, however, has prompted us to review again the nature of the agreement. And upon review, we find the matter of disengagement arising also in connection with:

1. Conversion to automatic operation;

2. Transfer of a department to another of the employer's plants;

3. Removal of the entire plant to another location; and

4. Shutdown of the plant and discontinuance of its operations.

It is submitted that disengagement ${ }^{13}$ from the union agreement, as manifested in the foregoing ways, will become the central concern of labor relations in practice, and of theorists seeking to agree on the legal nature of the collective agreement. The issue of contract disengagement is a matter of prime concern because it marks the point of collision between two inconsistent endeavors: the employer's desire to maintain or lower overhead in order to compete more effectively, ${ }^{14}$ and the employee's need to protect

13 The word "disengagement" presumes first that were there no contract or union the removal of jobs would proceed without restriction as long as it was not motivated by union animus; and second, that the contract must be deemed removed from the affected employces, either by its terms or by operation of law. This is borne out by the fact that whether a court, the Board, or an arbitrator allows or disallows the move it is decided on the basis of what the tribunal holds are the "rights" of parties in the presence of a contract. Inasmuch as these "rights" are only what the tribunal says they are, and inasmuch as there is as yet no consistent thread running through all the decisions, it is submitted that "disengagement from the contract" is the most useful concept to describe and relate the phenomenon of removing jobs from employees.

14 Analyses, purposes, and the extent of plant relocations are set forth in AFL, Subsidized Industrial Migration: The Luring of Plants to New Locations (1955); Conference of NEW England Governors Comom., Report of the New England TextILE Industry (1952); NPA Comanttee of the South, Rep't No. 3, Why Industry Moves South (1949); Seon工, The Labor Market and Plant Location (1960). 
the job that has become not only a livelihood but also the source of security, insurance, and income while laid off and after retirement.

An employee does not want to have his job removed from him for both economic and psychological reasons. ${ }^{15}$ The latter are obvious. The former consist of the following:

1. The present yield in job earnings is relatively high and indications are that it will continue to chmb;

2. Work time at a job produces income for retirement as well as for the years at work;

3. Consumer buying is to a great extent on credit with the result that the wage earner carries considerable current obligations for past purchases;

4. Shorter hours and good earnings permit both leisure and the means to enjoy it; and

5. Indemnity against costs of accident, and medical and hospital care, are made available by the job.

Exerting an equal force to remove that job is the employer's concern for the cost of it. ${ }^{16}$ The increasing benefits ${ }^{17}$ that the job pays have had to be absorbed through lower profit yield and higher prices in mixed combinations. The tendency to imcrease prices would likely not have been a problem if all goods were domestically produced. It is doubtful that wages as an item of overhead vary significantly among the large industrial areas where the skilled labor markets are located. The rapid growth of foreign economies and their industrial capacity, however, has introduced into our cussumer market comparable products of comparable quality at prices below those of domestic output. With competition thus broadened, management's desire to produce consumer goods and industrial equipment at lower prices

15 The mobility of workers is reduced by factors running contrary to the demands of a dynamic society, and an economy in transition.

a. The non-transferability of pension, seniority and other accumulated rights may result in an employee's being dependent upon his attachment to a particular job as the sole means of protecting his equities.

b. Desirable and essential mobility is affected by reluctance to leave bome-because of personal ties, or because other members of the family may be working; by the cost of moving and possible losses on local property; and by the imsecurity of jobs in a new locality.

"Benefits and Problems Incident to Automation and Other Technological Advances," Report of President's Advisory Committee on Labor-Management Pohicy, CCH LAB. L. REP. No. 116, at 4 (Jan. 11, 1962).

16 See BNA, Facts of Bargaining, No. 449, Aug. 17, 1962.

17 The average expenditure for fringe benefits (nonworking time wage items) in 1961, among 1,120 surveyed companies was $\$ 1,254$ per employee. In terins of payroll this is 61.6 cents per man per payroll hour or $24.9 \%$ of payroll. These figures are $\$ 122$ higher than 1959 per man per year and $2.1 \%$ higher than two years ago. Chamber of Commerce of the Uunted States Eighth Biennial Study of Fringe Costs, 50 LAB. REI. REP. 300 (1962). 
is not merely a matter of growth; it is a matter of survival. ${ }^{18}$ In short, the elements that have made the job of critical importance to the employee who holds it are among the factors that make it an item of overhead that the employer finds imcreasingly difficult to absorb.

This is the real issue before the courts, the NLRB, and the arbitrators when they consider plant removal, subcontracting, technological layoff, and the like. The basis of the legal jargon employed to discuss these phenomena is this intense management-union conflict, which should be accepted for what it is, be candidly considered, and be hopefully resolved.

\section{III}

\section{THE PRESENT TREATMENT}

The question of contract disengagement may be raised before an arbitrator, a court, or the National Labor Relations Board. Although the expressed issues vary little from one to another, the results vary considerably.

\section{A. The Courts ${ }^{19}$}

Two cases illustrate well the inconsistent treatment that has been and is likely to be given the employer's effort to remove a plant to another location. The district court, in Zdanok v. Glidden $\mathrm{Co}_{.}{ }^{20}$ permitted the removal, but the court of appeals reversed. ${ }^{21}$ In Oddie v. Ross Gear \& Tool Co., ${ }^{22}$ the district court did not allow the removal without an award of money damages to the disenfranchised employees, and the court of appeals reversed. ${ }^{23}$

18 The deep apprehension and even anguish of employees at seeing the machines on which they may work being taken from their plant and community is a distressing thing. History tells of many pathetic instances when employees have done all within their power to deter the departure from the community in which they live happily and have their beings, of the equipment which in this machine age [is] ... symbolic of their means of livelihood at the time. Some sucl situations have heartrending aspects, and it must be observed also that often they are of the gravest concern to those who operate production facilities, the employers and manufacturers, as well. But if they ignore economic realities such businesses cannot long exist. The bona fide economics are therefore the crux of the matter, in the absence of any specific agreement to the contrary.

Weyerhaeuser Co., 37 Lab. Arb. 308, 313 (1961) (Arbitrator Sembower), holding removal of machines to another plant did not violate agreement because (1) motivated by economic consideration, (2) contract did not specifically bar, (3) past practice, (4) no desire to subvert union, (5) job manning schedule is not a guarantee.

19 In his regular newspaper column, "In the Nation," Arthur Krock observed as a result of the Glidden and Ross decisions, "The trend of industry in areas of powerful unions, high taxes and high labor costs to reduce these burdens by moving their plants elsewhere has encountered serious obstacles in the Federal Courts." I.Y. Times, July 21, 1961, p. 22, col. 5.

20185 F. Supp. 441 (S.D.N.Y. 1960).

21288 F.2d 99 (2d Cir. 1961).

22195 F. Supp. 826 (E.D. Mich. 1961).

23 305 F.2d 143 (6th Cir. 1962). 
In the Glidden case, the Glidden Company's contract with the Teamsters expired on November 30,1957. The company decided to discontinue operations and close the plant at Elmhurst, Long Island, and establish a new plant at Bethlehem, Pennsylvania. Employees were offered the opportunity to apply for jobs at Bethlehem but only one did so. He was employed without credit for seniority accumulated at Elmhurst. The plaintiff employees did not challenge Glidden's right to close the plant nor did they suggest an improper motive for doing so. The sole issue was whether the seniority provisions of the expired contract survived the contract and were therefore entitled to be carried by the employees to new jobs at the Bethlehem plant. The district court rejected the plaintiffs' contentions that it was an implied condition of the bargain that the semority rights created by the contract would survive and that an alternative conclusion would make the contract illusory. The court construed the agreement to mean only what it said. Having been limited by its terms to operations at Elmhurst, when it expired and Elmhurst closed, nothing was left of the contract.

The Court of Appeals for the Second Circuit expressed a different view of the contract. The court held that even though the agreement provided in its preamble that it was made by Glidden "for and on behalf of its plant facilities located at . . . Elmhurst, Long Island, New York," a "rational construction of the contract would seem to require that the statement of location was nothing more than a reference to the then existing location ...." If not, the court continued, "the reasonable expectations of the parties are sacrified to sheer verbahism." Whereupon the court reversed and awarded the plaintiff employees damages on account of the company's breach of the seniority provisions of the expired agreement.

The Ross Gear case involved an action by employees of the Gemmer Division of The Ross Gear and Tool Company, in which they sought a declaration of their rights, an injunction against removal, and money damages. During the term of the collective agreement the company commenced its program to move its plant and operations from Detroit, Michigan to Lebanon, Tennessee. The contract by its terms was himited in coverage to the city of Detroit. While the trial court conceded, after a review of the history of the contract's negotiation, that the union may have bargained away its rights to represent the employees anywhere other than in Detroit, it held that there are "no geographical limitations as to the benefits of the employees and their rights under the contract." $" 25$

The theory of the court was that the employees' rights may not be unilaterally terminated by mere change of location. Nor will these rights ter- 
minate when the contract termination date is reached. The termination date is not the end of the contract; it "merely designates a certain time agreed upon by the parties when there would be further negotiations ....,20 The holding is neatly tied together in the court's conclusion that the agreement "vests" the employees with certain rights which cannot be unilaterally denied or withdrawn without their consent. These rights continue beyond the contract term and wherever the plant is located.

While the court cited with approval and followed the reasoning expressed by the Second Circuit Court of Appeals in Glidden, the Sixth Circuit Court of Appeals reversed, distinguished the Second Circuit and applied reasoning similar to that of the New York district court:

Whether it would be advisable or reasonable under the existing circumstances to have the agreement apply to the plant in Tennessee is not for the Court to decide. We must construe the contract as it is written, rather than make a new contract for the parties. ${ }^{27}$

\section{B. National Labor Relations Board}

Traditionally, the NLRB has held that management decisions having to do with subcontracting and the like are not included among the subjects of mandatory bargaining. ${ }^{28}$ Moreover, the actual decisions to disengage the contract have been permissible, provided that the disengagement is not motivated by an antiunion program and that the contract contains no express restriction on disengagement. ${ }^{20}$ Decisions have varied, however, as between the Board and the reviewing courts of appeal. But the variations were on the findings of fact; for example, as to whether the motive of disengagement was economic or antiunion. ${ }^{30}$

This traditional view has recently been reversed as the result of holdings of the Board which have converted the matters of plant relocation, ${ }^{31}$ subcontracting, ${ }^{32}$ and automation ${ }^{33}$ (acts of disengagement) to subjects of mandatory bargaining and hence matters no longer subject to unilateral

26 Id. at $830-31$.

27305 F.2d at 148.

28 Fibreboard Paper Prods. Corp., 130 N.L.R.B. 1558 (1961); Walter Folm \& Co., 87 N.L.R.B. 1169 (1949); Mahoning Mining Co., 61 N.L.R.B. 792 (1945).

29 See cases cited note 28 supre. We are not here concerned with the so-called "runaway shop" in which an antiunion notive for contract disengagement or avoidance is held to be an unfair labor practice. Deena Prods. Co., 93 N.L.R.B. 549 (1951), enforced, N.L.R.B. v. Deena Prods. Co., 195 F.2d 330 (7th Cir. 1952); Rome Prods. Co., 77 N.L.R.B. 1217 (1948).

30 NLRB v. Rapid Bindery, Inc., 293 F.2d 170 (2d Cir. 1961) ; Jay Foods, Inc. v. NLRB, 292 F.2d 317 (7th Cir. 1961).

31 Sidele Fashions, Inc., 133 N.L.R.B. No. 49 (1961).

32 Fibreboard Paper Prods. Corp., 138 N.L.R.B. No. 69 (1962) ; Town \& Country Mfg. Co., 136 N.L.R.B. No. 111 (1962). Compare Fibreboard Paper Prods. Corp., 130 N.L.R.B. 1558 (1961).

33 Renton News Record, 136 N.L.R.B. No. 55 (1962). 
determination. This change of policy can only be viewed as the Board's particular philosophical resolution of the conflict between the pressures of rising employer costs and the increasing concern by employees for job security.

Perhaps this is borne out by the rather flimsy basis of the Board's policy reversal: ${ }^{34}$ a Supreme Court decision construing the Railway Labor Act, ${ }^{35}$ a passing reference by the Supreme Court ${ }^{36}$ to an old and isolated Board decision, ${ }^{37}$ and not unexpectedly, the trilogy. ${ }^{38}$ The consequence which is pertinent to our discussion was well expressed in Member Rodgers' dissent to one of the new decisions:

The time involved in extensive negotiations and in protracted litigation before the Board, together with the numerous technical vagaries, practical uncertainties, and changing concepts which abound in the era of so-called "good faith bargaining," make it impossible for management to know when, if, or ever, any action on its part would be clearly permissible. ${ }^{39}$

Notwithstanding the sweeping shift of policy, there lingers the Board's recent holding in Lori-Ann of Miami, Inc. ${ }^{40}$ On a showing of extreme economic necessity the employer was permitted to disengage the contract and cease operations. It is noteworthy, however, that the employer ceased doing business altogether and that the decision included a determination that the employer had failed to give the union sufficient notice of closing.

\section{Arbitration}

The disengagement issue presented to arbitrators in most instances concerns subcontracting and plant removal. Peculiarly, where plant removal is the disengagement issue, the arbitrator (and the parties) have in many cases had the advantage of a union agreement which contains a clause specifically prohibiting removal of the plant either at all or beyond a specified distance. ${ }^{41}$ It appears in those cases that the removal and the arbitration occurred notwithstanding the written prohibition because the employer was pressed by severe economic conditions requiring decreased expenditures. Not unexpectedly, the employer finds no relief at the hands of the arbitrator charged with interpreting and applying the contract.

\footnotetext{
34 See Fibreboard Paper Prods. Corp., 138 N.L.R.B. No. 69 (1962).

35 Order of Telegraphers v. Chicago \& N.W.R.R., 362 U.S. 330 (1960).

36 Teamsters Union v. Oliver, 358 U.S. 283, 295 (1958).

37 Timken Roller Bearing Co., 70 N.L.R.B. 500 (1946), rev'd on other grounds, 161 F.2d 949 (6th Cir. 1947).

38 Cases cited note 10 supra.

39 Case cited note 34 supra.

40137 N.L.R.B. No. 114 (1962).

41 See Selb Mfg. Co., 37 Lab. Arb. 834 (1961); Jack Meilman, 34 Lab. Arb. 771 (1960); Centra Leather Goods Corp., 25 Lab. Arb. 804 (1956).
} 
Subcontracting cases, however, generally involve contracts that do not include a specific prohibition. ${ }^{42}$ In these instances, as with plant removal, the arbitrators are more and more inclined to take their cue from the Supreme Court's trilogy, which dealt with the arbitrability of union grievances against subcontracting not prohibited by contract. As an illustration, the arbitrator to whom the dispute was presented after the Supreme Court's decision in United Steelworkers v. Warrior \& Gulf Nav. Co., ${ }^{43}$ found that the subcontracting was indeed arbitrable and was limited not by what the contract stated but by an implied restriction upon management. ${ }^{44}$ That award reveals the larger significance of the trilogy. The arbitrator need no longer pretend to discern the parties" "intent" - a shibboleth worth disposing of anyway; he can ignore intent and even specific language and decide when he thinks it "fair" to allow disengagement of the contract, based on "rationality" or "good sense," rather than on what the parties agreed to in writing. Justice Douglas put it this way:

The labor arbitrator's source of law is not confined to the express provisions of the contract .... The labor arbitrator is usually chosen because of the parties' confidence in his knowledge of the common law of the shop and their trust in his personal judgment to bring to bear considerations which are not expressed in the contract. ${ }^{45}$

In more or less similar fashion arbitrators have dealt with other circumstances of contract disengagement. ${ }^{46}$ It is not necessary here to add to the large number of ably written articles that have reviewed and analyzed the trilogy, the court cases, and the arbitration awards dealing with an em-

42 As of 1960 , while $79 \%$ of the tallied contracts in manufacturing plants include management's rights clauses, only $25 \%$ contain provisions setting forth management rights respecting plant facilities and location and $19 \%$ respecting technological change. $52 \%$ of manufacturing plants include in their contract restrictions on management's rights. Only $13 \%$ deal specifically with subcontracting. 2 Cortective Bargatning-Negottations and Contracts 65:2 (1960).

One commentator reports that in only four of 1,637 major agreements studied was there an outright prohibition of subcontracting; 374 others contained various limitations on subcontracting. Lunden, Subcontracting Clauses in Major Contracts, 84 MONTHLY LAB. REv. 579, 581 (1961).

43363 U.S. 574 (1960). See note 10 suspra.

44 Warrior \& Gulf Nav. Co., 36 Lab. Arb. 695 (1961). It is significant also that Arbitrator Holly observed: "It is well established in arbitration that collective bargaining contracts which are silent on the subject of contracting out limit management's power to contract out." Id. at 699 .

45363 U.S. at 531-82.

46 Useful discussions of the present conflicts and inconsistencies among arbitrators dealing with similar contract clauses in the area of disengagement are: Celanese Corp., 33 Lab. Arb. 925 (1959) (Arbitrator Dash); Crawford, The Arbitration of Dispules Over Subcontracting, in Challenges to Arbitration 5I (1960); Feinberg, Transfer and Sale of Plant Operations in Arbitration, 13 LAB. L.J. 625 (1962). 
ployer's efforts to remove and transfer or discontinue all or a part of his plant production or maintenance facilities. ${ }^{47}$ The point is rather to examine the trend those decisions are marking out and to consider their impact on some major current questions.

\section{IV \\ CONSEQUENCES}

Among the matters that are called to consideration by the developing trend in the disengagement problem are:

A. To reconsider the validity of the view that the orgamized labor movement is on the decline;

B. To reconsider the nature of the collective bargaining agreement; and

C. To fashion and adopt a means of resolving the disengagement conflict so as to afford predictability as to what rights and duties a party has and has not.

\section{A. The Decline of the Labor Movement}

If the importance of the labor movement is measured simply in terms of numbers of members, one must acknowledge that if it is not declinning, it is certainly not growing significantly. ${ }^{48}$ The basic reason is understandable and may be simply expressed: the need for labor to be organized is diminishing. Industries presently under contract are not providing new members, for where the growth of manufacturing requires more machinery, it is automatic, not manual. Employees not now orgamized are likely to remain independent, largely because the wage and fringe policies unilaterally adopted by the company are designed, among other things, to compete effectively with what is offered employees under similar circumstances who are covered by union agreements. ${ }^{49}$ If a group of employees can obtain the

$47 \mathrm{~A}$ useful discussion of the legal aspects of Glidden is found in Plant Removal and the Survival of Seniority Rights: The Glidden Case, 37 IND. L.J. 380 (1962). For the practical aspects see Industrial Relations Counselors, Memro. No. 142, Plant RelocationIndustrial ReLations Implications (1962). See also Burstein, Subcontracting and Plant Removals, 13 LAB. L.J. 405 (1962).

48 In 1938 unions won $82 \%$ of Board conducted representation elections. See 3 NLRB ANN. REP. 49 (1938). In 1960 unions won 58.6\% of such elections. 25 NLRB ANN. ReP. 191 (1960).

49 As as exainple of an outside impediment to union growth, Solomon Barkin pointed out that:

Managenient had also sought to evolve a philosophy of personnel management that would guide it in its efforts to insulate enployees against outside umion influences. ... . The new approach had to replace or build upon earher systems of personnel policy, which rested on a fervent belief in management's primacy within the enterprise. Barkin, The Decltne of tie Labor Movement 18 (Fund for the Republic 1961). 
going wages, benefits, and job security (seniority) by the constant reminder that they may organize if dissatisfied, then their unionization will be indefinitely postponed. If that premise is acceptable, it follows that the failure of organized labor to attract new members in presently unorganized plants, companies, and industries is probably the most eloquent tribute that can be paid to the success of the labor movement. ${ }^{\text {so }}$

But the measure of the importance of organized labor is not its numbers. Rather it is labor's impact on the thinking of the judiciary, the legislatures, the executive branches of government. Applying this test, the labor movement is of growing importance. Its economists, attorneys, lobbyists, ${ }^{51}$ and theorists demonstrate a remarkable and effective coherence in their efforts to protect the integrity of unions and the jobs, earnings, and membership of the workers. Without oversimplifying the matter, one may regard the combination of labor's leaders in formulating and articulating protective policies, an enormous membership, effective lines of communication, and substantial funds as the means which have converted the mere views of organized labor into a potent political influence. Thus, Mr. Meaney's call for a thirty-five lour work week, while it may now be opposed, cannot be ignored, and one gets the feeling that, having been promoted by organized labor as a logical and necessary development, its acceptance may at most be postponed, but not defeated.

In this context, it is reasonable to view the growing resistance to disengagement, as manifested by the courts, the Board, and the arbitrators, as further evidence of organized labor's momentum in our nation's industrial society. This is well illustrated by the jurists' present tendency to look around the contract into the lieart of the worker. Justice Douglas wrote:

The parties expect that [the arbitrator's] ... judgment ... will reflect not only what the contract says but, insofar as the collective bargaining agreement permits, such factors as the effect upon productivity of a particular result, its consequences to the morale of the shop, his judgment whether tensions will be heightened or diminished. 5 ?

50 Unions have contracts in $73 \%$ of all industries, $79 \%$ of manufacturing, $95 \%$ of public utilities, $56 \%$ of wholesale trade, $39 \%$ of retail trade, and $56 \%$ of the service industries. 85 Montany LAB. REv. at II (June 1962).

DI In 1961, the second largest reported spending lobby in Washington, D.C., was the AFL-CIO at $\$ 139,919$; the tenth largest was the International Brotherhood of Teamsters at $\$ 81,918$. Intervening were the AMA, the American Farm Bureau, the American Legion, Savings and Loan League, Committee for Insurance Taxation, Farmers Union, Housing Conference, and American Trucking Ass'n, according to the Clerk of the House of Representatives and the Secretary of the Senate. McCarthy, A Senator Looks at Lobbies, N.Y. Times, Aug. 19, 1962, § 6 (Magazine), pp. 17, 76.

62 United Steelworkers v. Warrior \& Gulf Nav. Co., 363 U.S. 574, 582 (1960). (Emphasis added.) 
Judge Kaess wrote:

Although ... the agreement itself with the Umion as a bargaining agent might have been terminated by the move to Lebanon, the rights and benefits that have accrued to the individual employees persist and cannot be unilaterally denied by the employer without the employees' consent.53

Judge Madden, after dismissing the language of the contract as "sheer verbalism," stated:

We can see no expense or embarrassment to the [Glidden Company] ... which would have resulted from its adopting the more rational, not to say humane, construction of its contract [or from its] . . recognition . . . of riglts in its employees corresponding with their reasonable expectations. ${ }^{54}$

\section{B. The Nature of the Collective Bargaining Agreement}

It is easily apparent that courts and arbitrators have not treated the collective bargaining agreement as a contract. The school of thought that quite logically and traditionally concluded that what is not provided for in the agreement is reserved to management, is swiftly being swept before the tide of the "common law of the plant" and the "reasonable expectations of parties."

The footnotes, quotes, and conclusions of the trilogy opinions recall to us the thoughtful discussions of Cox, Shulman, and Chamberlaim ${ }^{55}$ on the nature of the collective bargaining agreement. While they do not agree on what it is, they do agree on what it is not, i.e., a contract. Perhaps the most appealing basis for concluding that it is not a contract in the traditional sense of that term was Mr. Cox's observation that the parties to it are not voluntarily associated with each other; they are not free, as in normal commercial relationships, to make independent judgments to do business with one another. The parties to a labor compact are forced upon one another and are forced to reach agreement. It follows that matters as to which the agreement is silent are not areas where they did not intend or did not want to reach agreement; rather they could not come to terms. Accordingly, it would be arbitrary to accord to one party or the other the flat right to make a unilateral decision in an area of contract silence. Viewing the relationship as involuntary but interdependent, Dean Shulman's thesis ${ }^{56}$ turns us to the plant's common law and common sense, upon the premise that both parties want uninterrupted production as their chief goal. added.)

53 Oddie v. Ross Gear \& Tool Co., 195 F. Supp. 826, 831 (E.D. Mich. 1961). (Emphasis

54 Zdanok v. Ghiden Co., 288 F,2d 99, 104 (2d Cir. 1961). (Emphasis added.)

55 See notes 5,8 \& 9 sucpra.

66 Shulman, Reason, Contract, and Law in Labor Relations, 68 HARv. L. REv. 999 (1955). 
Other theories of the status of the collective bargaining agreement which have been proposed are: ${ }^{57}$

1. Marketing theory--that the agreement is a statement of work rules;

2. Governmental theory-that the agreement is a kind of constitution which exists separate and apart from the state (the shop) and which assigns to labor and management specific roles in industrial government;

3. Managerial theory - that the agreernent provides the means of operation in those plants where, per the agreement, the union has a voice; and

4. Contract theory-that the union is the agent of its members and only matters provided for are within the orbit of the contract.

Although the status of the agreement has been the object of considerable concern for a variety of reasons, the failure to reach universal accord is a matter of increasing gravity. ${ }^{58}$ Contract disengagement, in its several forms, is a present expression of the economic problems of both management and employees. As long as that conflict exists, the parties, who clearly are unable to accommodate all of each other's interests and problems, should at least be provided reasonable expectations of what their rights and responsibilities will be determined to be when the agreement is put into the hopper of decision.

In short, the ad hoc approach to contract interpretation, without benefit of consistent theory or precedent, is altogether unsuitable to the newer economic conflict at the base of disengagement problems. Determining the status of the agreement is no longer merely an academic exercise, nor does the inability to do so affect only one or a few employees. The stakes are coming to be the survival of a plant or company. Neither the benefits an employee derives from his job nor the proper motives of enterprising management should be defeated by the accident of the philosophy of the arbitrator, court, or Board to whom the issue is presented. Nor should matters of that magnitude depend for their resolution on the resourcefulness of counsel, the inconclusive discussions of the last negotiating session, or the ability of either party to sustain a work stoppage in support of its view as to the inclusion or phraseology of a particular contract clause.

${ }^{5 T}$ Burstein, Status of the Collective Bargaining Agreement, in UNIONS, MANAGEMENX, AND THE PUBLIC 279 (2d ed. 1960).

58 Various theories of management authority or the extent of it under a union contract are proposed by a number of writers. See, e.g., Davey, The Arbitrator Views the Agreement, 12 LAB. L.J. 1161, 1166 (1961); Torrence, More Comments on Security and Management Authority, 12 LAB. L.J. 285, 289 (1961). 


\section{A Proposal for Allowing Disengagement}

The time has come to abandon the present system of allowing or disallowing disengagement of all or part of a contract.

Recall that the opinions in the trilogy alluded to the federal common law of labor relations. When tested, one is hard pressed to know what is referred to by the "federal common law." Presumably it is the conglomerate of decisions which the federal courts are handing down. But if the opimions and holdings in the Glidden and Ross Gear litigations are any indication, and it is submitted that they are, one cannot know what the federal common law is. In fact, the notion of a federal common law is just short of absurd ${ }^{59}$ when it depends for its formulation on the collective, conflicting holdings of the courts of appeals and all the district courts contained therein and, as of late, the courts of the several states. ${ }^{60}$ And to suggest that these conflicts are of no import because the Supreme Court shall resolve them, necessarily casts that court directly into the role of a legislature of nine lifetime appointees, whicl while frequently the case, we hesitate to acknowledge and would resist promoting.

The clear alternative would seen to be a thouglitfully drafted statutory law enacted by the Congress which may be presumed to be able to hear, resolve, and incorporate in legislation the reasonable and necessary interests of labor unions, employees, and management. While the final enactment would not reflect all the wishes of each group, it would necessarily provide the elenient that all parties correctly seek in an economic relationship, be it voluntary or involuntary, namely some degree of predictability of what the rights and responsibilities of the parties are upon the occasion of the contract's disengagement.

Appropriate legislation would prescribe:

1. What disengagement is comprised of:
a. Plant removal
b. Departmental transfer
c. Subcontracting
d. Plant closing
e. Technological innovation

59 But for a more optimistic appraisal of the potential of a uniform federal common law of labor contracts see Jay, Arbitration and the Federal Common Law of Collective Bargaining Agreements, 37 N.Y.U.L. REv. 448 (1962).

${ }^{60}$ See Teamsters Umion v. Lucas Flour Co., 369 U.S. 95 (1962); Charles Dowd Box Co. v. Courtney, 368 U.S. 502 (1962). 
2. The circumstances in which the employer may disengage the contract:

a. Contract provisions permitting

b. Economic circumstances notwithstanding contract provisions

3. Provisions for the status of labor union representative upon disengagement-whether permitted to continue at a new location and, if so, under what circumstances

4. Provisions for employees' rights upon disengagement:
a. Notice of disengagement
b. Severance pay
c. Offer of continued employment
d. Costs of moving and transfer
e. Status of benefits
f. Training and retraining opportunities

5. A forum for the settlement of disputes

It would seem that the best forum for resolving disputes would be one that provides the speediest procedure for decision and whose decisions will serve as precedent in the consideration of subsequent sinuilar questions. The National Labor Relations Board, under an expedited procedure, would fit these requirements. Moreover, it would not be difficult to fit into the present structure of the Labor Management Relations Act provisions for additional acts which would constitute unfair labor practices both for the employer who ignores the prescribed conditions of disengagement and for the union or employees who seek to impede or interfere with the progress of the complying employer.

Critics of this approach might well suggest that one defect is removing from the area of free and private bargaining and agreement a most basic matter of mutual concern; that disengagement is a subject for the parties to agree upon without legislative interference. Nornally this observation would be valid and appealing. It is submitted, however, that legislation is the only nieans of providing what we now are sorely lacking-a certain right to disengage with predictable responsibilities by adherence to prescribed procedure available under worthy circumstances. 